\title{
Modern Banking And Strategic Portfolio Management
}

Reza G. Hamzaee, (E-mail Address: hamzaee@missouriwestern.edu), Missouri Western State University \& Walden University Bob Hughs, Missouri Western State University

\begin{abstract}
In this research, an analysis of modern banking in a competitive environment is provided. Modern banking operations would involve dynamic strategic planning, in which a clear mission is declared, various strategies are formulated, and certain objectives and goals are placed in order. The banking industry in various countries has gone through some evolution. The growing competitive conditions, both inside and outside the industry, have influenced the banks' investment in diverse assets and adoption of various forms of liabilities, which will be discussed here. Risk analysis, risk management, and operations under uncertainties would put a bank's survival and/or failure under a critical observation. This research provides a practical manual on bank investment under uncertain conditions, in which various kinds of risk are involved. While a competitive treatment of customers has always been of a critical significance to financial stability of banks, appropriate strategic decisions on investment choices and techniques have distinguished the thriving from the struggling banks. Among those alternative investment choices, one may clearly find the investment practices under varying interest-rate conditions of prime significance. The influence of cyber-technology on banks' services, policy making, forms of money \& credit, including, e-money, electronic payments, digital cash, smart cards, online banking, etc., has attracted special attention by all the stakeholders. The authors will address the following three questions: 1. What portfolio structure in a variable interest-rate environment is proven to be most profitable? 2. What are the most appropriate products that modern banks must provide to their customers? 3. How is the task of risk management implemented by some successful banks?
\end{abstract}

\section{INTRODUCTION}

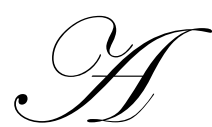

$s$ the American economy goes through periods of expansion and contraction it becomes necessary for the depository institutions, to control their costs, while managing their assets most effectively. American depository institutions include commercial banks, credit unions, savings institutions, and savings \& loan institutions. Financial institutions must be able to effectively manage their exposure to various types of risks, including interest rate risk, credit, default, and other risks. The fluctuation in an uncertain future presents an opportunity for financial institutions to implement strategies for selecting an appropriate asset allocation plan. While short term variations in the interest rates within a year are fairly predictable, longer-term variations involve higher uncertainties. Many business and consumer loan commitments, involving real estate, can extend out several years up to 30 years.

The American economy has matured beyond the 1800's cycles of rapid booms and busts. With a rather successful implementation of the control of the money supply and the creation of a Federal Funds rate, the discount rate, and reserve requirement, the Federal Reserve System has been able to smooth out the business cycles. This has created an environment in which both businesses and consumers are more comfortable and able to take on more debt that will become burdensome during deflationary times (Miller and VanHoose, 2004). It has also allowed financial institutions to focus more on controlling credit and default risk. An optimal portfolio selection, including an appropriate mixture of loan commitments, will be the focus of this paper. Theoretical modeling, data collection, and examination of the model will also follow. 
During the period of 2001-2003, the Federal Funds rate was decreased very rapidly enabling depository institutions to lend at lower cost. However this new debt-allocation strategy has reversed itself because since the mid 2004, the Federal Funds rate has increased, posing an interest rate problem for these institutions. This problem, interest rate risk, develops through changes in the market value of the banks' financial instruments due to changes in the interest rates (Miller, 2004).

\section{The Research Questions}

The research questions here are:

1. What portfolio structure in a variable interest-rate environment is proven to be most profitable?

2. What are the most appropriate products that modern banks must provide to their customers?

3. How is the task of risk management implemented by some successful banks?

\section{A STRATEGY MAP AND EVALUATION OF A COMPANY (BANK)}

The following is a strategy map, suggested by Atkinson et al (2004), which provides a visual exhibition of the linkages in the four perspectives of the Balanced Scorecard.

\section{Figure 1}

\section{Connecting the Four Perspectives}

\section{A strategy map provides a visual representation of the linkages in the four perspectives of the BSC (Balanced Score Card)}

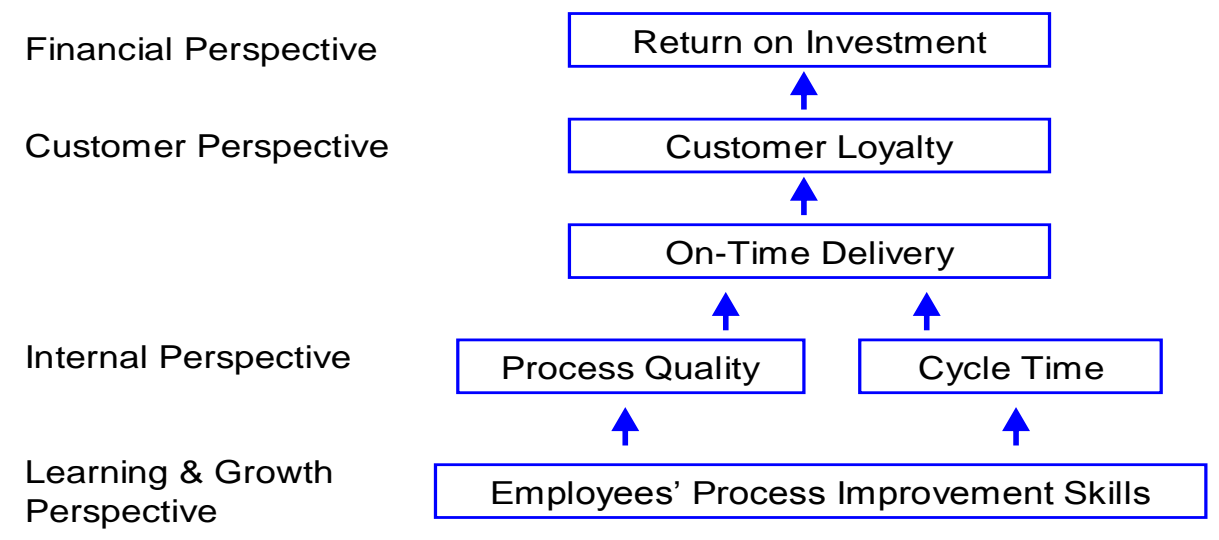

Source: Management Accounting, Anthony A. Atkinson, Robert S. Kaplan, and S. Mark Young, Pearson Prentice Hall, 2004. (AKY)

A bank's main value, given the quality and liquidity of its assets, is mainly determined by the following accounting identity (Kasper, 1997):

$\mathrm{A} \equiv \mathrm{L}+\mathrm{E}$

Where, $\mathrm{A}=$ total assets, $\mathrm{L}=$ total liabilities, $\mathrm{E}=$ owner's equity 


\section{Intrinsic Value}

The price of a stock that one is willing to pay is considered as the current value that equated some future payoff $=\mathrm{P}_{\mathrm{t}}$ (which is also the price per share at the end of period $\mathrm{t}$ )

$\mathrm{P}_{0}(1+\mathrm{k})=\mathrm{E}\left(\operatorname{Div}_{1}\right)+\mathrm{E}\left(\mathrm{P}_{1}\right)$

Then: $\mathrm{P}_{0}=\left[\mathrm{E}\left(\operatorname{Div}_{1}\right)+\mathrm{E}\left(\mathrm{P}_{1}\right)\right] /(1+\mathrm{k})$

where:

$\mathrm{P}_{0}=$ the present value of the expected payoff, and

$\mathrm{k}=$ the market capitalization rate

Also:

$\mathrm{P}_{0}+\mathrm{P}_{0} \mathrm{k}=\mathrm{E}\left(\operatorname{Div}_{1}\right)+\mathrm{E}\left(\mathrm{P}_{1}\right)$

$\mathrm{k}=\mathrm{E}\left(\mathrm{Div}_{1}\right) / \mathrm{P}_{0}+\left[\mathrm{E}\left(\mathrm{P}_{1}\right)-\mathrm{P}_{0}\right] / \mathrm{P}_{0}$

The first term is the expected dividend yield, and the second term is the expected rate of price appreciation. Therefore the $\$$ return from an investment of $\mathrm{P}_{0}$ at rate $\mathrm{k}$ is:

$\mathrm{P}_{0} \mathrm{k}=\mathrm{E}\left(\mathrm{Div}_{1}\right)+\left[\mathrm{E}\left(\mathrm{P}_{1}\right)-\mathrm{P}_{0}\right]$

Example: What is the fair current price of a stock with an expected dividend per share of $\$ 5$, an expected price of $\$ 110$ at the end of the first period, and an annual market capitalization rate of $15 \%$ ?

$\mathrm{P}_{0}=(\$ 5+\$ 110) / 1.15=\$ 100$

Intrinsic values of a stock at the beginning of the year 1

$\mathrm{P}_{1}=\left[\mathrm{E}\left(\mathrm{Div}_{2}\right)+\mathrm{E}\left(\mathrm{P}_{2}\right)\right] /(1+\mathrm{k})$

Plugging (6) into (3):

$\mathrm{P}_{0}=\mathrm{E}\left(\operatorname{Div}_{1}\right) /(1+\mathrm{k})+[1 /(1+\mathrm{k})]\left\{\left[\mathrm{E}\left(\operatorname{Div}_{2}\right)+\mathrm{E}\left(\mathrm{P}_{2}\right)\right] /(1+\mathrm{k})\right\}$

$\mathrm{P}_{0}=\mathrm{E}\left(\operatorname{Div}_{1}\right) /(1+\mathrm{k})+\left[\mathrm{E}\left(\operatorname{Div}_{2}\right)+\mathrm{E}\left(\mathrm{P}_{2}\right)\right] /(1+\mathrm{k})^{2}$

That implies that the intrinsic value today is equal to the discounted sum of the first two years= dividends plus the discounted terminal value at the end of year 2 .

$$
\begin{aligned}
& \mathrm{P}_{0}=\left.\sum_{\mathrm{t}=1}^{\mathrm{T}}\left[\mathrm{E}\left(\operatorname{Div}_{\mathrm{t}}\right) /(1+\mathrm{k})^{\mathrm{t}}\right]+\left[\mathrm{E}\left(\mathrm{P}_{\mathrm{T}}\right)\right] /(1+\mathrm{k})^{\mathrm{T}}\right] \\
&\left.\mathrm{P}_{0}=\lim _{\mathrm{T} \rightarrow \infty} \sum\left[\mathrm{E}\left(\operatorname{Div}_{\mathrm{t}}\right) /(1+\mathrm{k})^{\mathrm{t}}\right]+\lim _{\mathrm{T} \rightarrow \infty}\left[\mathrm{E}\left(\mathrm{P}_{\mathrm{T}}\right)\right] /(1+\mathrm{k})^{\mathrm{T}}\right] \\
& \mathrm{P}_{0}=\lim _{\mathrm{T} \rightarrow \infty} \sum\left[\mathrm{E}\left(\operatorname{Div}_{\mathrm{t}}\right) /(1+\mathrm{k})^{\mathrm{t}}\right]
\end{aligned}
$$




\section{A PRACTICAL DECISION MAKING ENTAILING UNCERTAINTY \& RISK}

One of the challenges that must be successfully met by bank managers is the selection of most appropriate assets (loans, securities, etc.), when the future is uncertain. However, maintaining the historical records, would help the manger come up with smartest, yet not surest, decisions. In the following table, assume that three groups of assets, say A, B, and C are identified (from the bank's historical records) to render the indicated rates of returns along with their corresponding (calculated) probabilities. Then the following general statistical formula for expected value of $\mathrm{X}$ is applied (Miller and Pulsinelli, 1989):

Expected Value of $X=E(X)=X_{1} \cdot P_{1}+X_{2} \cdot P_{2}+\ldots \ldots+X_{n} \cdot P_{n}$

where, $\mathrm{X}$ could be the value of a loan or a composite investment, with all possible outcomes of $\mathrm{X}_{1}$ with a probability of $\mathrm{P}_{1}, \mathrm{X}_{2}$ with a probability of $\mathrm{P}_{2}, \ldots \ldots$, and $\mathrm{X}_{\mathrm{n}}$ with a probability of $\mathrm{P}_{\mathrm{n}}$.

Table 4: Asset Selection Involving Uncertainty \& Risk

\begin{tabular}{|c|c|c|c|}
\hline Assets & Historical Rate of Return & Probability & $\begin{array}{c}\text { Expected Rate of Return } \\
=\mathbf{E}(\mathbf{X})=\mathbf{X}_{\mathbf{1}} \cdot \mathbf{P}_{\mathbf{1}}+\mathbf{X}_{\mathbf{2}} \cdot \mathbf{P}_{\mathbf{2}}\end{array}$ \\
\hline Group A & $10 \%=\mathrm{X}_{1}$ & $(.10)(.40)+(.15)(.60)=13 \%$ \\
& $15 \%=\mathrm{X}_{2}$ & $40 \%=\mathrm{P}_{1}$ & $(.20)(.50)+(.06)(.50)=13 \% ?$ \\
\hline Group B & $20 \%=\mathrm{X}_{1}$ & $60 \%=\mathrm{P}_{2}$ & \\
& $6 \%=\mathrm{X}_{2}$ & $50 \%=\mathrm{P}_{1}$ & $(.20)(.20)+(.06)(.80)=8.8 \%$ \\
\hline Group C & $20 \%=\mathrm{X}_{1}$ & $50 \%=\mathrm{P}_{2}$ & \\
& $6 \%=\mathrm{X}_{2}$ & $20 \%=\mathrm{P}_{1}$ & \\
\hline
\end{tabular}

In the above table, while the bank's logical choice between the three asset groups of $\mathrm{A}, \mathrm{B}$, and $\mathrm{C}$ is not $\mathrm{C}$, some bank managers may prefer investment in assets of group A more appealing than those of group B due to the group A's tighter gap between its best and worst possible outcomes, where the risk and the extent of variations is more limited. However, based on the expected rate of return, as the only criterion, both A and B groups would be identical.

One question that a good banker may have is how to calculate the aforementioned probabilities. Those are easily calculated from the bank's recorded historical data. As an example, one may consider 5-10 years of data on, e.g., loans. Focus on all loans which were granted at $10 \%$ rate of interest, and then take the number of those loans granted at all other alternative rates. Then, the following ratio will serve the purpose:

The probability of loans rendering a $10 \%$ rate of return $=$

(The number of loans granted @ 10\%)

(The number of loans granted @ all other alternative rates)

That would be true under the following assumptions:

- $\quad$ All the loans included in the above calculation were good loans.

- $\quad$ The values and amounts of loans could be either taken equal across all loans or one may just consider similar loan amount brackets, e.g., $\$ 50,000-\$ 60,000$ bracket, as well as other brackets.

\section{Valuing a Depository Institution's Assets}

The valuation of a depository institution's assets is commonly done in the following two ways, leading to often a wide difference (Atkinson, Kaplan, and Young, (2004):

\section{Market value accounting}

An accounting procedure in which a depository institution (or its regulator) values its assets in terms of the approximately current (secondary market) prices, at which those assets would currently sell 


\section{Historical Value Accounting}

A traditional accounting procedure in which a depository institution's assets are always valued at their original values not the current market prices.

When interest rates change, many banks find themselves in a vulnerable condition, especially if the rates go up too much. One reason for that is the fact that what keeps a bank in business is primarily the difference between its interest earnings (on loans or bonds and securities) and its interest expenses (on deposits). If a bank has already invested a big part of its portfolio in long-term (20-30 year fixed) low-interest loans, the increasing interest rates under the competitive conditions, would force the bank to offer higher interest rates on deposits. That would be a recipe for bank's diminishing profits or increasing losses, especially if the interest-rate upward movement continues for some rather long time. This was a clear reason for the insolvency of a great number of U.S. banks and depository institutions in the 1980s.

\section{PORTFOLIO STRUCTURE DECISIONS}

Financial institutions have long used models as a means of reducing their exposure to risk. Whether the size of the financial institution assets is small, mid-sized, or large, the ability to minimize interest rate risk through portfolio management and the use of derivatives has become very demanding. The most common methods of addressing interest rate exposure include maturity gap analysis and repricing schedules with most banks and the use of interest rate swaps and other derivatives with primarily larger banks (Saunders and Cornett, 2003 and Basel, 2003). With the use of the later, Financial Institution's are increasing exposing themselves to other risks, including credit and market risk.

In various periods of banking history, the use of variable rate loans have been replaced by fixed rate loans as interest rates change (Santomero, 1983). For Financial Institution's their income, or cash flows, as well as many underlying assets are tied to interest rates. Their portfolio of assets and liabilities are all sensitive to interest rate changes. Assets could include T-Bills, T-notes, short-term consumer loans, and variable rate mortgages. Liabilities could include short-term CD's, time deposits, and short-term commercial paper. The shorter the terms of the assets or liabilities, the more interest rate sensitive these balance sheet items are. The wide availability of these assets and liabilities does not make the Financial Institution's function of portfolio mixture simple, focusing on short term instruments leaves the FI susceptible to interest rate risk. While focusing on long term instruments can create devastating effects inn rapid interest rate changes.

With gap analysis, much attention is paid to a dynamic portfolio mixture including Variable Rate Liabilities (VRLs) and Variable Rate Assets (VRAs). To insure duration matching, where duration is the average life of an asset or liability, weighted or otherwise (Saunders and Cornett, 2003), banks also include Fixed Rate Liabilities (FRLs) and Fixed Rate Assets (FRAs). The purpose of duration matching allows bank to begin to safeguard themselves against movements in interest rates. The maturity gap, which is the weighted-average maturity of the Financial Institution's assets and liabilities (Saunders and Cornett, 2003), can be written as $\left(\mathrm{M}_{\mathrm{A}}-\mathrm{M}_{\mathrm{L}}\right)$, i.e., the weighted-average maturity of the assets $\left(\mathrm{M}_{\mathrm{A}}\right)$ minus its liability counterpart $\left(\mathrm{M}_{\mathrm{L}}\right)$. Most banks hold asset with durations longer than their liabilities (Saunders and Cornett, 2003). In effect they are lending at longer terms than the terms of their investments. In this case a rise in the interest rate will result in a reduction in the present value of the financial institution's assets. The longer the duration of their assets, or $\mathrm{M}_{\mathrm{A}}-\mathrm{M}_{\mathrm{L}}>0$, the stronger will be the balance sheet effects.

Banks also deploy the use of re-pricing variable rate assets and liabilities to ensure they have an accurate understanding of their exposure to interest rate risk. The Basel Committee, an international body that is working on standardizing banking practices throughout the world to ensure accountability and accuracy of information, recommends that policy makers of financial institutions be made aware of their exposure through simple and complex models of re-pricing (Basel, 2003). Re-pricing can include variable- rate assets and liabilities being marked to market, as frequently as their data will allow them. Marked to market is the repricing of an asset or liability as the cash flows of the underlying asset changes with interest rates. Repricing the schedules of a banks assets and liabilities and adjustments in maturities historically have been the methods banks have used to control interest rate risk. 
However, over the last twenty years an increasingly popular method of interest rate control has been the use of derivatives, such as interest rate swaps. One example of a interest rate swap is a bank exchanging one set of cash flow for another set of cash flow. For instance, a bank heavy with variable-rate assets (VRAs) can exchange the cash flows of a bank that is heavy in fixed-rate assets (FRAs), also known as a vanilla swap. This exchange allows banks to alter their income streams, without changing the value of their portfolio. Larger banks are increasingly using derivatives to counter the effect of interest rate risks, leaving them more exposed to credit risk. This ability to undertake the heavy use of derivatives arrives from the ability to employ a staff to accomplish successful derivative trading and brokering. The majority of banks failures are the result of credit risk and becoming a concern of regulators (Simons, 1995).

Non-systematic or idiosyncratic risk can be defined as those that can be minimized and possibly eliminated through an appropriate portfolio structure. These risks can appear within certain financial instruments. In the case of lending, a financial institution has the ability to control non-systematic risks such as price risk and credit risk of their customer through the underwriters. In addition, the ability to prepare for non-systematic risks using diversification can ensure that when an event occurs, such as a natural disaster or an international banking crisis, liquidity can be ensured. Diversification or the process of holding a variety of financial instruments whose price movements are not correlated is descriptive to non-systemic risk. In the process of minimizing both non-systematic risks some amount of profit is foregone, as capital is restricted from being leveraged through the use of loans (Saunders and Cornett, 2003). Systematic risk or market risk can be defined as risks that cannot be eliminated nor can the time of the event be predicted. As such, this risk cannot be reduced or eliminated through a process of diversification (Miller and VanHoose, 2004).

\section{SUCCESSFUL IMPLEMENTATION OF INTEREST RATE RISK MANAGEMENT}

Banks across asset classes consistently have maturity gaps and levels of liquidity that appear to be the same proportions (Simons, 1995). In an empirical study that was done in 1995 gathering data from the Quarterly Call Report, Simon found that large banks used derivatives much more than smaller banks. Simon also found that the asset-liability mixes as well as duration gaps seem to be consistent as well, which may lead to a conclusion that duration gap and the proper mix of assets and liabilities are fundamentally important for banks to minimize interest rate risk.

Under the Basel accord (2003), it is recommended that banks begin to have portfolio mixes that allow them to absorb more of an interest rate shock. In the United States, we have had numerous occasions of shocks from the 911 terrorist attacks and numerous costly hurricanes which could result in unexpected interest rate changes and shocks. The recommendation of Basel is that portfolios have an adequate mixture of durations among their fixed and variable rate assets and liabilities. This would allow financial institutions to have additional capital available through highly liquid investments. Doing so would prevent the most catastrophic event financial institutions fear and that is a run on a bank, in which depositors seek to withdraw their deposits faster than financial institution's liquidity can provide.

In regards to the use of derivatives, the additional risk that are involved make these tools more interesting for larger financial institutions if they are open to such risks. Smaller and mid-sized financial institutions often do not have the staff to perform such functions. Focusing on ensuring a bank will not experience a run on the bank, and maintaining an appropriate portfolio of assets and liabilities will prove to be successful for these institutions. Moreover, derivative usage allows them to maintain capital requirements while altering portfolio duration through swaps. Having a portfolio mixture where VRAs>VRLs will allow a bank to absorb increases in interest rates by replacing the lower-rate with higher-rate assets. Their balance sheets will be favorably affected, however in similar proportions. FRAs and FRLs optimally would have a parallel shift on the balance sheet when interest rate changes (Saunders and Cornett, 2003). In the following all-scenario cases, proposed by the authors and mainly based on Miller and VanHoose (2004), this concept will be clearer. 


\section{Asset-Liability Management Strategies:}

In this section, a strategic financial management for a typical bank is analyzed to illustrate how a bank manager may overcome the uncertainty involved in varying interest rates. Briefly, the following issues should be discussed and understood:

- The Main Objective: Coordination (or management) of all balance sheet items in a way that the PV of the shareholders' shares will be maximized

- $\quad$ The Strategy: Designing appropriately the relative structures of variable-rate assets (VRAs) \& variable-rate liabilities (VRLs) @ all times

- $\quad$ Definition of VRA, \& VRL: Assets (VRAs) \& liabilities (VRLs) that can be re-priced due to changes in interest rates, risks, \& expectations; they can be renewed \& rolled over during the bank's planning horizon

- $\quad$ Definition of FRA, \& FRL: Fixed-Rate Assets (FRAs) and Fixed-Rate Liabilities (FRLs) cannot be re-priced due to changes in interest rates, risks, \& expectations; they cannot be renewed $\&$ rolled over during the bank's planning horizon. These are normally long-term assets and liabilities.

- Definition of "a Funds Gap": VRAs - VRLs = A Funds Gap, which reflects the sensitivity of a Bank's net interest earnings (its profits) to variations in the (domestic \&/or international) market interest rates.

\section{Three Operational Examples:}

(Example 1)- The Zero-Funds Gap Strategy: Suppose that the manager is facing a relatively stable environment, where there are minimum interest rate variations and thus, minimum interest-rate risks. Interest rates do not change that much. The ideal asset-liability management of the bank would be simplified in the following balance sheet type of portfolio:

VRA $=40 \%$ of the portfolio (of all the assets) FRA $=60 \%$ of the portfolio (of all the assets)
VRL $=40 \%$ of all the liabilities $\mathrm{FRL}=60 \%$ of all the liabilities

Where the correct portfolio structure is summarized as:

$$
\frac{V R A}{\text { total assets }}=\frac{V R L}{\text { total liabilities }}
$$

(Example 2)-The Positive-Funds Gap: Now, let's take a case, in which the economy is not heading for a recession, and it is expected that interest rates will go up. In this case, a positive-funds gap strategy would be necessary, which is summarized below:

$$
\frac{V R A}{\text { total assets }}>\frac{V R L}{\text { total liabilities }}
$$

That would raise the net interest earnings (in VRAs versus VRLs) of the bank.

The risk here is larger since if interest rates actually go down unexpectedly, then the present value of the FRAs \& FRLs will go up and net interest earnings for the bank would go down. 


\begin{tabular}{|l|l|}
\hline VRA $=60 \%$ of all the assets & VRL $=30 \%$ of all the liabilities \\
& \\
\hline FRA $=40 \%$ of all the assets & \\
& \\
\hline
\end{tabular}

(Example 3)-The Negative-Funds Gap: What if the economy is heading for an economic recession, and/or for whatever reason the expectations are that interest rates will go down?

A negative funds gap strategy would be appropriate in this case, which is summarized as:

\section{$\frac{V R A}{\text { total assets }}<\frac{V R L}{\text { total liabilities }}$}

That would:

- $\quad$ raise the net interest earnings (in VRAs versus VRLs) of the bank

- $\quad$ raise the present value of the FRAs more than that of the FRLs

This is why the Basel accords (2003) recommend that an oversight board be established and it should be clearly understood who is in charge and under what circumstances procedures should be enacted. Risky lending and improper oversight of procedures would prove to be ineffective in the long run, as they are viewed with no more credibility as gambles, this urging is directed towards the use of derivative usage.

\begin{tabular}{|l|l|}
\hline VRA $=30 \%$ of all the assets & \multicolumn{1}{|l|}{ VRL $=60 \%$ of all the liabilities } \\
\hline \multirow{2}{*}{ FRA $=70 \%$ of all the assets } & \\
& FRL $=40 \%$ of all the liabilities \\
\hline
\end{tabular}

Short term loan policy changes can easily affect a financial institution's portfolio mix; it is the long term assets and liabilities that become the concern. In addition, these short-term loans and instruments provide the greatest cash flow in and out of the balance sheet. 


\title{
PRODUCT OFFERINGS OF FINANCIAL INSTITUTIONS
}

\author{
Modern banking activities are adjusted to the modern needs of their customers. In this section a summary of \\ a typical American modern bank's products and services is presented: \\ - $\quad$ Checking \& Saving Accounts \\ - $\quad$ Time Deposits (or Certificates of Deposit, CD) \\ - $\quad$ Trust Funds \\ - $\quad$ Money Market Deposit Accounts \\ - $\quad$ Bankers' Acceptances \\ - $\quad$ Borrowed Federal Funds (overnight deposits of other banks at another bank @ a slight rate of interest) \\ - $\quad$ Automatic Bill Payments \\ - $\quad$ Automatic Transfers of Funds \\ - $\quad$ Pension Investments \\ - $\quad$ Tax Filing Services \\ - $\quad$ Payroll-Payment Services \\ - $\quad$ Insurance Services \\ - $\quad$ Import-Export Services \\ - $\quad$ Gift Cards to Small Businesses (Wells Fargo \& Co., started August 2004) \\ - $\quad$ Free Checking Accounts to Small Businesses \\ - Wachovia Corp. woos small- business customers with discounts on everything from office supplies and hotel \\ rooms to express shipping services. \\ - $\quad$ Credit Cards \\ - $\quad$ Online Banking \\ - $\quad$ Business Savings Accounts \\ - Wire Transfers \\ - $\quad$ Lines of Credit \\ - Term-Loans \\ - $\quad$ SBA Loans \\ - $\quad$ Equipment Leasing Loans \\ - $\quad$ Repurchase Agreements (Repos or RPs)
}

Banks find themselves in very difficult situations as customers begin to look at competitive rates of investments. The increasing ease of Internet banking removes geographical walls as customers have their bills and deposits automatically deposited. The ability of the consumer to experience digital banking creates new opportunities for bricks and mortar banks to provide services at little or no cost to the customer. Investing in human capital remains important for these institutions, because an unpleasant experience may cause a customer to move their deposits from Banks A to Bank B. The ability of banks to maintain deposits will ensure they will have capital to leverage through the use of loans. As commercial banks merge with investment banks and integrate higher profit margin products to customers as a means to decrease costs, customers will the affected. Customers begin to see prices and fee reduced as banks compete increasingly on their more profitable products and the internet will increase that process. As this occurs banks will need to ensure that their relationships with their customers remain on good terms (Carlson and Perli, 2001).

Another era, in which modern banks have found themselves very profitable has been through the interest rate declines in the first years of the $21^{\text {st }}$ century. As consumers and business's worked to consolidate debt and refinance existing debt to take advantage of low interest rates, banks profited from the associated fees they charge for these services (Carlson and Perli, 2001). In the same article, Carlson and Perli discuss that the declining interest rates and the ability of borrowers to decrease payments and avoid late payments and defaults, perhaps helped a declining economic environment from worsening. This increase in profits for commercial banks, generated by fees, is an attractive alternative ways of generating revenue. Fees on many general banking services have already become part of the standard banking packages. These include: online banking, mailed statements, notary and other signature 
guarantee services, as well as others, which are recently provided freely to customers due to market competitive pressures.

Lowering costs through services such as Check Clearing for the $21{ }^{\text {st }}$ Century Act (Check 21) can be one way for banks and retailers to reduce costs (Institute of Management \& Administration, 2004). A change in Federal law has allowed banks that process check to electronically submit them to the crediting banks. This in turn reduces the cost of insuring checks and transporting checks. While this service is only a year old, large banks are beginning to find that it enables them to receive their money even quicker and at lower costs. For the person writing the check, the scanned copy of the check is a legal copy that can be used to dispute false claims against their accounts.

Commercially, banks would want to offer customers the ability to decrease their costs. For example, the process of direct depositing payroll checks has allowed a reduction in both employment and transportation costs. For individual patrons of banks, the continued availability of automatic payment of bills, online banking, and investments with competitive interest rates will continue to be their focus. As more and more banks begin to offer financial services, the trend towards a separate place for investment, banking, and insurance needs begin to change. Regardless, the trends remain toward offering customers additional services under one roof. The growth in this area will continue to be distinguished between the smaller and the larger banks (Carlson and Perli, 2001).

\section{CONCLUSION \& SUMMARY}

In this research, modern banking in a competitive environment is analyzed. Modern banking operations would involve dynamic strategic planning, in which a clear mission is declared, various strategies are formulated, and certain objectives and goals are placed in order.

The growing competitive conditions, both inside and outside the banking industry, have influenced the banks' investment in diverse assets and adoption of various forms of liabilities, which will be discussed here. Risk analysis, risk management, and operations under uncertainties would put a bank's survival and/or failure under a critical observation. This research has hopefully provided a practical manual on bank investment under uncertain conditions, in which various kinds of risk are involved. It has addressed the following three questions:

1. What portfolio structure in a variable interest-rate environment is proven to be most profitable?

2. What are the most appropriate products that modern banks must provide to their customers?

3. How is the task of risk management implemented by some successful banks?

\section{BIBLIOGRAPHY}

1. Atkinson, Anthony A., Kaplan, Robert S., and Young, S. Mark. (2004). Management Accounting, Pearson Prentice Hall.

2. Basel Committee on Banking Supervision. (September 2003). Principles for the management and supervision of interest rate risk. Bank for International Settlements.

3. Bounds, Gwendolyn. (March 8, 2005). Banks Expand Services, Perks For Small Firms, The Wall Street Journal, pp. B1 and B10.

4. Bringham, Eugene F., Gapenski, L. C., \& Ehrhardt, M. C. (1999). Financial Management, $9^{\text {th }}$ edition, The Dryden Press.

5. Checkley, Keith. (1999). Cash Is Still King, Glenlake Publishing Co., Ltd. (American Management Association).

6. Carlson, Mark and Perli, Roberto. (2003). Profits and Balance Sheet Developments at U.S. Commercial Banks in 2003.

7. Foerster, Stephen R. (2003) Financial Management: A Primer, New York: Norton.

8. Galitz, Lawrence. (1995). Financial Engineering: Tools and Techniques to Manage Financial Risk, Pitman Publishing, London.

9. Hamzaee, Reza G. (1987). Fiscal \& Monetary Policy: An International Perspective, Copley Publishing Group. 
10. Hamzaee, Reza G. (May 1991). Supply of Money, Economic Activity, and Interest Rates, Regional Business Review, Northwest Missouri State University, Vol. 10, pp. 91-97.

11. Hamzaee, Reza G. (1994). About the Autonomy of the Federal Reserve System, National Social Science Journal, pp. 192-206.

12. Hawawini, Gabriel A., \& Viallet, Claude. (1999). Finance for Executives: Managing for Value Creation, Southwestern College Publishing.

13. Institute of Management \& Administration (August 2004). "Check 21" and what it means to the credit and collections department. Managing Credit, Receivables \& Collections.

14. Kasper, Larry J. (1997). Business Valuations: Advanced Topics, Quorum Books.

15. Miller, Roger LeRoy, Pulsinelli, Robert W. (1989). Modern Money and Banking, $2^{\text {nd }}$ edition. McGraw-Hill Book Company.

16. Miller, Roger LeRoy, VanHoose, David D. (2004). Money, Banking, and Financial Markets. Mason, Ohio: South-Western.

17. Santomero, Anthony (December 1983). Fixed Versus Variable Rate Loans. The Journal of Finance, 13631380.

18. Saunders, Anthony, Cornett, Marcia Millon. (2003). Financial Institutions Management. $4^{\text {th }}$ Edition. New York, NY: McGraw-Hill.

19. Sihler, William W. \& Crawford, Richard D., and Davis, Henry A. (2004). Smart Financial Management, American Management Association.

20. Simons, Katerina. (January-February 1995). Interest rate derivatives and asset-liability management by commercial banks. New England Economic Review, 17-29.

21. Shoup, Gary. (1998). Currency Risk Management, Glenlake Publishing Co., Ltd. (American Management Association). 


\section{NOTES}

